\title{
ANTIBACTERIAL POTENCY OF CHITOSAN OLIGOMER PRODUCED BY Bacillus licheniformis MB-2 CHITOSANASE
}

\author{
Ekowati Chasanah ${ }^{1)}$, Meidina ${ }^{2)}$, and Maggy T. Suhartono ${ }^{3)}$ \\ 1) Marine Biotechnology Lab, Center for Marine and Fisheries Product Processing and \\ Biotechnology Research-Petamburan, Jakarta \\ 2) Food Science Program, Graduate School, Bogor Agricultural University-Bogor, Indonesia \\ 3) Department of Food Science Technology, Faculty of Agricultural Technology, Bogor Agricultural University-Bogor, Indonesia \\ Received September 26-2007; Received in revised form March 25-2008; \\ Accepted October 24-2008
}

\begin{abstract}
Bacillus licheniformis MB-2 chitosanase isolated from hot spring water in Manado, Indonesia, was used to produce chitosan oligomers. Both crude and pure Bacillus licheniformis MB-2 chitosanase were used to prepare chitosan oligomers, and the antibacterial activity of the resulting oligomers were tested towards 6 pathogenic bacteria, including Pseudomonas aerugenusa, Salmonella typhimurium, Escherichia coli, Staphylococcus aureus, Listeria monocytogenes, and Bacillus cereus. By contact method, the oligomers, at the MIC value (Salmonella typhymurium of $321 \mathrm{ppm}$, Pseudomonas aeruginosa, Staphylococcus aureus, and Escherichia coli (MIC of $402 \mathrm{ppm}$ ) and the contact time of 24 $\mathrm{h}$, were able to reduce all pathogenic bacteria tested by 2 to $5 \mathrm{log}$ cycles. Using Pseudomonas aeruginosa protease, the oligomers were capable of reducing the protease activity by $64 \%$, indicating that antiprotease might be involved in the antibacterial mechanism by these oligomers.
\end{abstract}

KEYWORDS: Bacillus licheniformis MB-2 chitosanase, oligomer, antibacterial agent, protease inhibitor

\section{INTRODUCTION}

Chitosan is a natural polymer containing $\mathrm{N}$-acetyl$D$-glucosamine and $D$-glucosamine residues. Having biodegradable and biocompatible properties, this deacetylated form of chitin polymer has been used widely at various industries such as food, agricultural, pharmaceutical, and waste water treatments. To improve its application, i.e enhancing the water solubility properties, the polymer is usually modified by substituting the functional groups with chemical substances or partially hydrolyzed chemically or enzymatically. Application of enzyme for partially degrading chitosan was more preferable because of the mild and safe process as well as specific reaction, resulting in high quality oligomer products. Specific size oligomer was reported to maintain various prominent biological activities such as antimicrobial properties.

Study on antimicrobial properties of chitosan has been reported by a number of scientists (Sagoo et al., 2002; Helander, 2001; Rhoades \& Roller, 2000; Muzarelli et al., 1990; El-Ghaouth et al., 1992). At low $\mathrm{pH}(<6.3)$, chitosan polymers showed antifungal activity (Roller \& Covill, 1999; Rhoades \& Roller, 2000). Partially degraded chitosan or chitosan oligomer was reported to have antibacterial properties against some pathogenic bacteria compared to the native one (Kendra \& Hadwiger, 1984). The antibacterial mechanism has been proposed as loosing of barrier function of bacterial cell wall caused by chitosan binding to the outer membrane of bacteria, and Chung et al. (2004) reported that there was a positive relationship between antibacterial activity of chitosan and surface characteristics of bacterial cell wall. Another possible mechanism through inactivation of important enzymes such as protease has never been reported yet.

Bacillus licheniformis MB-2 has been isolated from hot spring water of Manado and be able to produce thermostable chitosanase. In pure form, the enzyme hydrolyzes specifically chitosan, producing pentamer and hexamer of chitooligosaccharide (Chasanah, 2004). Preliminary study on antibacterial properties of oligomers from the crude enzyme using 4 concentration ( 0.005 tp $0.170 \mathrm{U}$ per mg chitosan) showed that oligomer produced by applying $0.1 \mathrm{U}$ per $\mathrm{mg}$ chitosan and reaction time of 1 to 3 hours was able to reduce the 6 pathogenic bacteria tested (Meidina et al., 2004). Further study on the sensitivity and mechanism of antibacterial through their potency as anti protease was assesed in this study using $P$. aeruginosa protease. Six pathogenic bacteria frequently associated with food borne infection and intoxication was used.

\section{MATERIALS AND METHODS}

\section{Chemicals}

Chitin and chitosan ( $85 \%$ deactylated) were purchased from Sigma. Colloidal chitosan (about $76 \%$ 
deacetylated) was chemically prepared from chitosan by method of Trudel and Asselin (199). All other reagents were of analytical grade. Pseudomonas aeruginosa, Staphylococcus aureus, Salmonella typhimurium, Escherichia coli were obtained from Pertamina Hospital, Jakarta, while Listeria monocytogenes and Bacillus cereus was from Veterinery Research Institute, Bogor. Commercial antibiotics, i.e kanamycin, amphicillin, and cephotaxim was used as control, obtained in $5 \mathrm{mg}$ vial.

\section{Microorganism and Enzyme Production}

Bacillus licheniformis MB-2 was cultivated in medium consisted of $0.24 \%$ chitosan, $0.25 \%$ casiton, $1 \% \mathrm{MgSO}_{4}, 1.4 \% \mathrm{~K}_{2} \mathrm{HPO}_{4}, 0.02 \% \mathrm{CaCl}_{2} .2 \mathrm{H}_{2} \mathrm{O}$, $0.002 \% \mathrm{FeSO}_{4} .7 \mathrm{H}_{2} \mathrm{O}(\mathrm{pH} 7.0)$, and incubated at $55^{\circ} \mathrm{C}$, $120 \mathrm{rpm}$ shaker waterbath. A seed culture (15\%) ( $\mathrm{pH7.0)}$ of the bacteria (18 h) was used. The supernatant containing the enzyme was collected after centrifuging the fermentation broth at $8,000 \mathrm{~g}$ for $20 \mathrm{~min}$. The enzyme was further concentrated by addition of $80 \%$ saturated ammonium sulphate.

\section{Purification}

Cell free supernatant containing 30\% saturat $\_d$ ammonium sulphate $(75 \mathrm{ml})$ was applied unto hydrophobic Butyl Sepharose 4 fast flow matrix, which had been previously equilibrated with $30 \%$ saturated ammonium sulphate to $0.05 \mathrm{~m}$ phosphate bufer $(\mathrm{pH} 6)$. After sample application, the column was washed with the same buffer, and the eluate was obtained by washing with linear gradient of $15 \%$ saturated ammonium sulphate phosphate buffer $(0.05 \mathrm{~m}, \mathrm{pH} 6)$ and $0.05 \mathrm{~m}$ phosphate buffer (without ammonium sulphate) with elution rate of $2 \mathrm{ml}$ per $\mathrm{h}$. Each fraction $(3 \mathrm{ml})$ was collected, and the protein and chitosanase activity were measured.

\section{Chitosanase Assay}

Chitosanase assay was conducted according to Yoon et al. (33), with modifications. The reaction mixture consisting of 100 il of $1 \%$ colloidal chitosan, $100 \mathrm{il} 0.05 \mathrm{~m}$ phosphate buffer ( $\mathrm{pH} \mathrm{6)}$ and $100 \mathrm{il}$ of the enzyme solution was incubated at optimum temperature for $30 \mathrm{~min}$. The reaction was stopped by incubating the mixture at $-10^{\circ} \mathrm{C}$ for $15 \mathrm{~min}$. The amount of reducing sugar in the mixture was determined by a modified method of Schales (27). An amount of 200 il of the solution was further mixed with $1 \mathrm{ml}$ schales

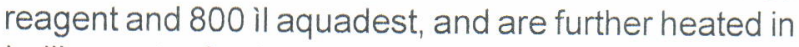
boiling water for 15 minutes, centrifuged for $10 \mathrm{~min}$ at $3,000 \mathrm{~g}$ and the absorbance was read at $\ddot{e}=420 \mathrm{~nm}$. A blank was prepared using aquadest. One unit of chitosanase activity was defined as the amount of the enzyme which produces 1 ìmol of reducing sugar (glucosamine) per minute.

\section{Protein Determination}

Protein content was determined based on Bradford method using bovine serum albumin as the protein standard at 0.2 to $1.2 \mathrm{mg}$ protein per $\mathrm{ml}$. The reaction mixture contained $100 \mathrm{il} \mathrm{of} \mathrm{sample,} 1 \mathrm{ml}$ of aquadest and $1 \mathrm{ml}$ Bradford reagent. After vortexing the mixture, the absorbance was read at $595 \mathrm{~nm}$. A blank was prepared by substituting sample solution with 100 il of aquadest.

\section{Chitosan Oligomer Preparation}

Oligomer chitosan was made by reacting the enzyme (0.1 unit per mg chitosan), both crude and pure, to 1 of $85 \%$ deacetylated chitosan for 1 hour (Meidina et al., 2004). Oligomer was harvested by boiling the mixture to inactivate the enzyme followed by sentrifugation $(10,000 \mathrm{rpm}, 10$ minutes). The oligomer (supernatant) was sterilized at $121^{\circ} \mathrm{C}, 15$ minutes before applied for antibacterial test.

\section{Viability Study of Pathogenic Bacteria}

Bacterial viability was analyzed by contact method (Carson \& Riley, 1995). Bacterial culture amounting to $10^{4} \mathrm{CFU}$ per $\mathrm{ml}$ were incubated along with chitosan oligomer, and incubated in medium broth at $37^{\circ} \mathrm{C}$. The number of bacteria at $0,1,3,11$, and 24 hours were plated and counted as colony forming unit per $\mathrm{ml}$ The chitosan oligomer concentration used was 1 and 1.5 MIC value (Meidina et al., 2004)

\section{Identification of Chitosan Oligomer}

Chitosan oligomer formed was identified using dual lambda 440 mode HPLC, with 60\% acetonitrile solvent in water as the moving phase. Detection was based on retention time. The flow rate speed used was $1 \mathrm{ml}$ per min. The oligosaccharides standard (monomer to hexamer of glucosamine) was used at $1 \%(\mathrm{w} / \mathrm{w})$.

\section{Chitosan oligomer as anti protease}

Protease enzyme was produced by inoculating 1 ose of Pseudomonas aeruginosa into LB and incubated for $24 \mathrm{~h}$ in $37^{\circ} \mathrm{C}$ shaker water bath. Extracellular protease was harvested by centrifuging the broth at $10,000 \mathrm{~g}$ for $15 \mathrm{~min}$. Protease was assayed using $2 \%$ casein according to Bergmeyer et al. (1983). 
Inhibitor protease was analysed according to Anson In Imada et al. (1989).

\section{RESULTS AND DISCUSSION}

\section{Enzyme and Oligomer Production}

Bacillus licheniformis MB-2 chitosanase was harvested at the seventh days of fermentation using $15 \%$ starter, at $55^{\circ} \mathrm{C} 120 \mathrm{rpm}$ shaker bath. Crude enzyme was obtained by concentrating the cell free supernatan with $80 \%$ saturated ammonium sulphate. Purification was done by hydrophobic interaction colomn chromatography as previously mention, and the relatively pure enzyme (Figure 1, Fraction 2 ) was collected.
Oligomer chitosan was made by reacting the enzyme, both crude, and pure, to 1 of $85 \%$ deacetylated chitosan. Optimal concentration of the crude enzyme effectively retarded the 6 pathogenic bacteria tested was $0.1 \mathrm{IU}$ per mg chitosan with reaction time of 1 to $3 \mathrm{~h}$ (Meidina et al., 2004). The diameter of a clear zone as antibacterial indication was about 10 to $19 \mathrm{~mm}$ for the 6 pathogenic bacteria.

This concentration was used in this experiment with reaction time of $1 \mathrm{~h}$. For pure enzyme, the same concentration was used. In this experiment, oligomer possesing antibacterial properties was identified based on HPLC analysis. It was found that oligomer mixture were in the from of 2 to 6 unit oligomer.

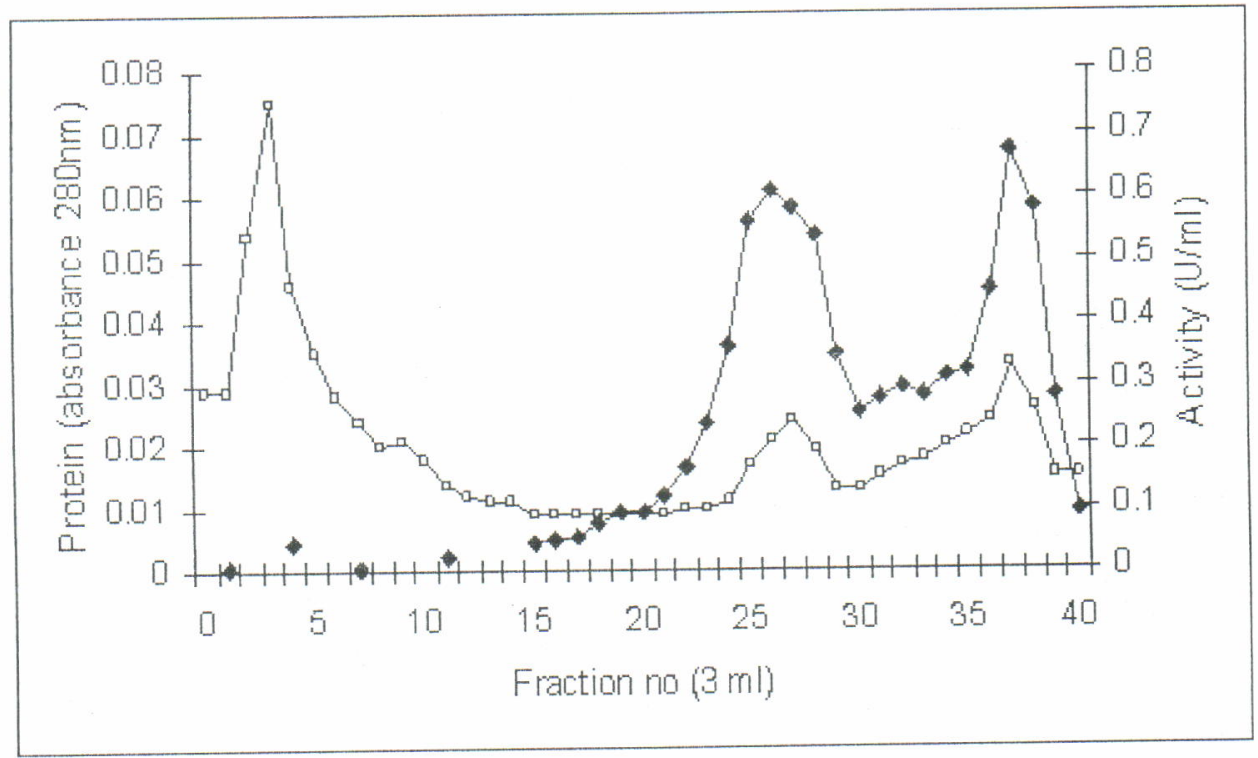

Figure 1. Elution profile of chitosanase and protein during hydrophobic interaction chromatography using Butyl Sepharose 4 FF matrix.

Remarks: • = chitosanase activity; $1=$ absorbance $280 \mathrm{~nm}$

\section{Antibacterial Study}

Previous study by Meidina resulted that MIC value of oligomer produced by the crude chitosanase, was lower (321 to $562 \mathrm{ppm}$ ) compared to the polymer chitosan (7,000 to $10,000 \mathrm{ppm})$, but it was much higher compared to the commercial antibiotics (5 to $100 \mathrm{ppm}$ ). The MIC value of Salmonella typhymurium was 321 ppm, while the MIC of Pseudomonas aeruginosa, Staphylococcus aureus, and Escherichia coli were $402 \mathrm{ppm}$, and the MIC of Listeria monocytogenes and Bacillus cereus were 482 and 562 ppm, respectively.

In this study, antibacterial potency of the oligomer was assesed by viability study. The concentration of oligomer used was at the MIC and 1.5 MIC, and the number of bacteria survived was counted during certain time as indicated at Figure 2 below. Results showed that, in general, the number of all bacteria tested was reduced during 11 hours contact time. It was assumed that during that time all oligomer were already bound to the cells, and increasing bacterial number after that time may indicated the survived bacteria were capable to regain replication. The $1.5 \mathrm{MIC}$ used was not significantly shown different effect to the number of bacterial reduction. Among bacteria tested, Pseudomonas aeruginosa was the most sensitive. The number of the Pseudomonas aeruginosa was significantly reduced during the first 3 hours contact, while Escherichia coli and Salmonella typhimurium were significantly reduced by 11 and 24 hours contact. On the other hand, gram positive pathogenic bacteria tested were reduced not as much as those gram negative bacteria. The results was in agree with 
previous research results (Chung et al., 2004; Helander et al., 2001). It was reported that there was a positive relationship between antibacterial activity of chitosan and surface characteristics of bacteria cell wall. Gram negative bacteria which has more negative charged and more hydrophilic were more sensitive to oligomer chitosan compared to the gram positive bacteria. Chitosan oligomer produced by pure chitosanase did not give different inhibition results as the crude one
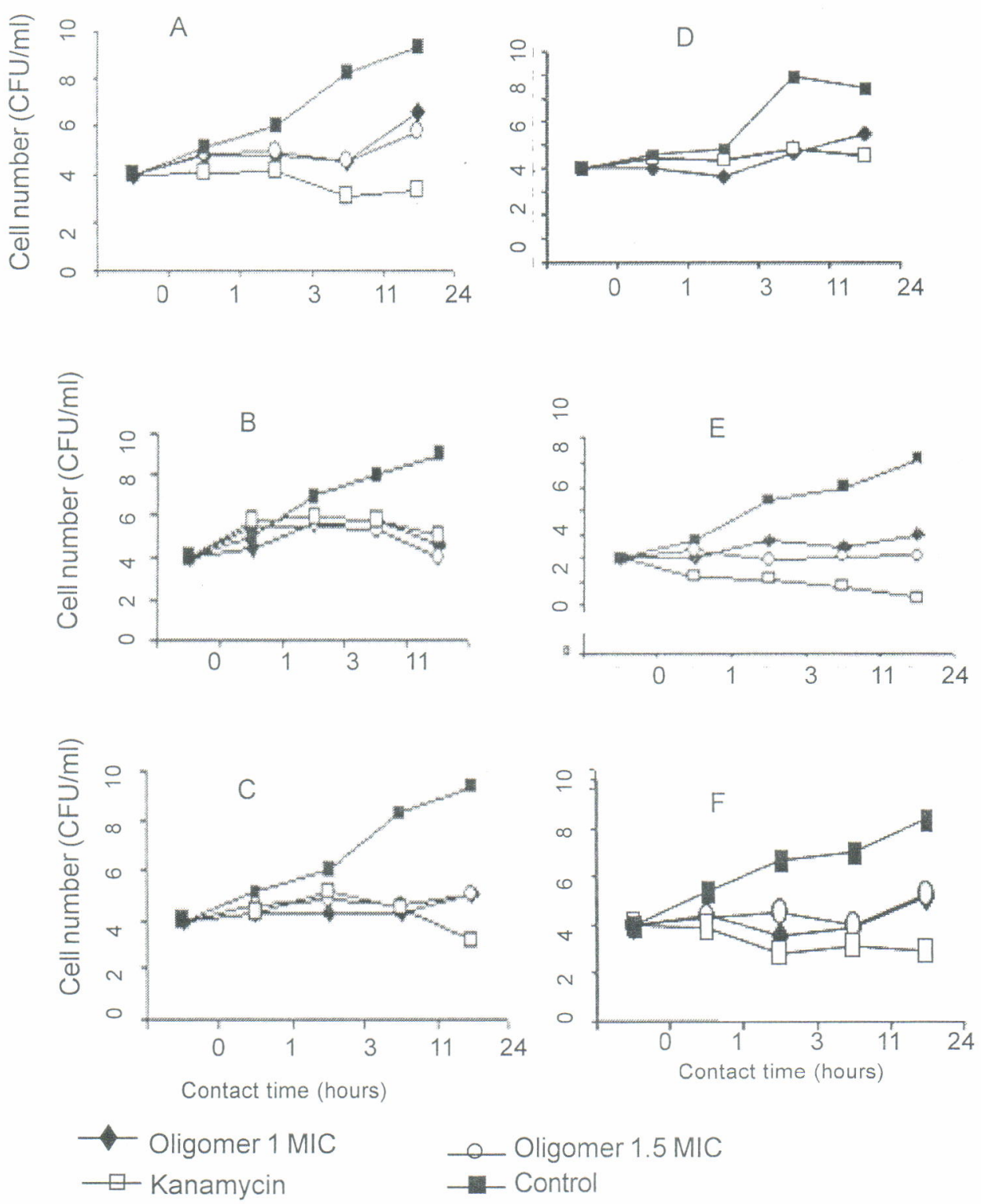

Figure 2. Effect of chitosan oligomer concentration and contact time on to cell viability ( $A=P$ seudomonas aeruginosa; $\mathrm{B}=$ Salmonella typhimurium; $\mathrm{C}=$ Escherichia coli $\mathrm{D}$ = Staphylococcus aureus; $\mathrm{E}=$ Listeria monocytogenes; $\mathrm{F}=$ Bacillus cereus).

\section{Anti Protease Activity of the Oligomer}

Protease enzymes presented in bacterial cell surface has important role in defensive mechanism. It was hypothized that protease secreted by pathogenic bacteria was known as toxin, and some other were hydrolytic enzymes capable of degrading extracellular matrix compounds of host polymer, for their carbon and energy sources.

In this experiment, chitosan oligomer produced by Bacillus licheniformis MB-2 was assessed for antiprotease. Results showed that chitosan oligomer at their MIC were able to retard $64 \%$ of Pseudomonas 
aeruginosa protease having activity of $0.09 \mathrm{U}$ per $\mathrm{ml}$, while $25 \%$ retardation was obtained when using chitosan oligomer at $0.5 \mathrm{MIC}$. From the result, it can be deduced that the ability of chitosan oligomer, produced by Bacillus licheniformis MB-2 chitosanase, to inhibit pathogenic bacteria might through antiprotease mechanism.

\section{CONCLUSIONS}

1. Chitosan oligomers produced by Bacillus licheniformis MB-2 chitosanase has capability of reducing the 6 pathogenic bacterial tested by 2 to 5 log CFU per ml during 24 h contact.

2. Gram negative bacteria were more sensitive to the chitosan oligomer than the gram positive one.

3. The oligomers, at MIC value, was able to inhibit Pseudomonas aeruginosa protease by $64 \%$, suggesting that the ability to inactivate bacterial protease might be one of the antimicrobial mechanisms performed by chitosan oligomer.

\section{ACKNOWLEDGMENT}

We acknowledged research support from Program B, Department of Food Science Technology, Faculty of Agricultural Technology, Bogor Agricultural University. The initial work was started through the cooperation between Research Center for Biotechnology, Bogor Agriculture University, Bogor, Indonesia and Bioproduct Research Center, Yonsei University, Seoul, Korea.

\section{REFERENCES}

Bergmeyer, H. U., J. Bergmeyer, \& M. Grafi. 1983. Methods of enzymatic analysis. Vol.2. Weinheim. Verlag Chemie. Hal.1.007-1.009.

Carson, C. F. \& T. V. Riley. 1995. Antimicrobial activity of the major components of the essential oil of Melalueca alternifolia. Journal Appl Bacteriol. 78. 264-269.

Chasanah, E. 2004. Characterization of chitosanase of Bacillus licheniformis MB-2 from Manado hot spring water. Dessertation. Institut Pertanian Bogor. Bogor. Indonesia.
Chung, Y. C., Y. P. Su, C. C. Chen, G. Jia, H. I. Wang, J. C. G. Wu, \& J. G. Lin. 2004. Relationship between antibacterial activity of chitosan and surface characteristics of cell wall. Acta Pharmacol Sin. 25. 932-936.

El-Ghouth A., R. Ponnampalam, F. Castaigne, \& J Arul. 1992. Chitosan coating to extent the storage life of tomatoes. Hortsci. 27. 1.016-1.018.

Helander, I. M., E. L. Nurmiaho, R. Ahvenainen, J. Rhoades, \& S. Roller. 2001. Chitosan disrupts the barrier properties of the outer membrane of Gramnegative bacteria. Int Journal Food Microbiol. 71. 235-244.

Imada, C., U. Simidu, \& N. Taga. 1989. Isolation and characterization of marine bacteria producing alkaline protease inhibitor. Bulletin Japanasse Soc Scientific Fishery. 51. 799-803.

Kendra, D. F. \& L. A. Hadwiger. 1984. Characterization of the smallest chitosan oligomer that is maximally antifungal to Fusarium solani and elicits pisatin formation in Pisum sativum. Exp Mycol. 8. 276281.

Meidina, B. S. L. Jenie, Sugiyono, \& M. T. Suhartono. 2004. Aktivitas antibakteri oligomer kitosan yang diproduksi menggunakan kitosanase dari isolat Bacillus licheniformis MB-2. Seminar Nasional PATPI. Jakarta.

Muzarelli, R. A. A., R. Farsi, O. Filippini, E. Giovanetti, G. Biagini, \& P. E. Varaldo. 1990. Antimicrobial properties of N-Carboxybutyl chitosan. Antimicr Agents Chemoth. 34. 2.019-2.023.

Roller, S. \& N. Covill. 1999. The antifungal properties of chitosan in laboratory media and apple juice. Int. Journal Food Microbiol. 47. 67-77.

Rhoades, J. \& S. Roller. 2000. Antimicrobial actions of degraded and native chitosan against spoilage organism in laboratory media and foods. Appl. and Enviroment Microbiology. Jan. 80-86.

Sagoo, S., R. Board, \& S. Roller. 2002. Chitosan inhibits growth of spoilage microorganisms in chilled pork products. Food Microbiol. 19. 175-182. 
